\title{
PENGARUH PERILAKU MASYARAKAT YANG BERMUKIM DI KAWASAN BANTARAN SUNGAI TERHADAP PENURUNAN KUALITAS AIR SUNGAI KARANG ANYAR KOTA TARAKAN (Influence of The Behavior of Citizens Residing in Riverbanks to The Decrease of Water Quality in The River of Karang Anyar Tarakan City)
}

\author{
Ira Puspita ${ }^{1 *}$, Linda Ibrahim² dan Djoko Hartono ${ }^{3}$ \\ 1Program Magister Ilmu Lingkungan, Program Pascasarjana, Universitas Indonesia \\ Jl Salemba Raya No.4, Jakarta 10430. \\ ${ }^{2}$ Fakultas Ilmu Sosial dan Ilmu Politik, Universitas Indonesia, \\ J1 Prof Dr. Selo Soemardjan Depok 16424. \\ ${ }^{3}$ Fakultas Teknik, Universitas Indonesia, Jl Prof Dr. Selo Soemardjan Depok 16424.
}

*Penulis korespondensi. Tel: 085216160887. Email: irapuspita1979@yahoo.com.

Diterima: 24 Agustus 2015

Disetujui: 16 Januari 2016

\begin{abstract}
Abstrak
Data Status Lingkungan Hidup Daerah Kota Tarakan menyatakan bahwa kualitas air Sungai Karang Anyar Kota Tarakan yaitu parameter COD, amoniak dan TSS tahun 2010-2013 melebihi baku mutu. Penurunan kualitas air tersebut disebabkan oleh perilaku masyarakat yang bermukim di kawasan bantaran sungai. Pendekatan penelitian kualitatif dengan menggunakan gabungan metode kualitatif dan kuantitatif. Metode kuantitatif antara lain digunakan untuk teknik pengumpulan data melalui kuesioner dan menghitung status mutu air Sungai Karang Anyar menggunakan metode Indeks Pencemaran. Metode kualitatif antara lain digunakan untuk observasi, wawancara mendalam kepada swasta dan tokoh masyarakat. Hasil penelitian yaitu perilaku masyarakat yang membuang air limbah domestik langsung ke sungai mempengaruhi parameter COD melebihi baku mutu karena air limbah yang dibuang terdapat busa sabun berasal dari buangan air cucian. Air limbah domestik yang dibuang langsung ke sungai berasal dari sisa memasak sehingga diduga menyebabkan amoniak juga melebihi baku mutu. Perilaku masyarakat yang tidak mengolah kotoran ayam dapat mempengaruhi parameter amoniak melebihi baku mutu karena kotoran ayam membusuk dan mengalir ke sungai. Perilaku masyarakat yang mengambil tanah dari bukit/gunung tidak mempengaruhi parameter TSS karena dipengaruhi mengambil tanah dari bukit/gunung dilakukan pada curah hujan menurun/kemarau. Perilaku masyarakat yang menambang pasir di sungai mempengaruhi parameter amoniak melebihi baku mutu karena air limbah domestik yang organik dan kotoran ayam membusuk yang telah tertimbun lama di dasar sungai akan terangkat. Perilaku masyarakat yang menambang pasir di sungai tidak mempengaruhi parameter TSS karena kegiatan menambang pasir tidak dilakukan setiap hari dan bergantung pada curah hujan. Sebagai kesimpulan adalah tidak semua perilaku masyarakat yang bermukim dan berkegiatan di kawasan bantaran sungai mengakibatkan penurunan kualitas air sungai.
\end{abstract}

Kata kunci: bantaran sungai, kualitas air sungai, limbah cair, limbah domestik, parameter dan perilaku masyarakat.

\begin{abstract}
The data of environmental status of Tarakan City states that water quality of Karang Anyar's river for COD, ammonia and TSS paremeters from year 2010-2013 are above the government regulation for quality standard. The decreasing of Karang Anyar's river water quality are influenced by the behavior of regional society along the riverbanks. Research methods used in this research is the combination between quantitative and qualitative methods. The result of this research are the disposal of domestic waste water directly into the river suspected in affecting the parameters COD and ammonia exceeded the quality standard because waste water contains foam of soap sources from waste water of wash. The disposal of domestic waste water from cooking residue in affecting ammonia parameters exceeded the quality standard. The behavior of livestock chicken was suspected affecting ammonia parameter in exceeding the quality standard because of chicken's feces have been decomposed. Mining soil behavior from hills or mountains suspected not affecting TSS parameter because of climate influenced. The behaviour of sand river's mining suspected affecting ammonia parameter and exceeding the quality standard but did not affect TSS parameter because the activities were not daily and the miners depending on rain level and sand volume. The conclusion of this research are the not all behavior of regional society along the riverbanks affect the decreasing of Karang Anyar's river water quality.
\end{abstract}

Keywords: riverbanks, river water quality, waste water, domestic waste, parameter and behavior. 


\section{PENDAHULUAN}

Ada keterkaitan antara jumlah penduduk (manusia) dan penurunan kualitas lingkungan hidup. Penurunan kualitas lingkungan hidup oleh manusia terdiri atas 3 faktor yaitu jumlah manusia, jumlah sumberdaya alam yang dipergunakan oleh setiap manusia, dan dampak lingkungan dari sumberdaya alam dipergunakan (Miller, 1982). Jumlah penduduk (manusia) yang meningkat dan bermukim di bantaran sungai akan mempengaruhi perilaku seseorang. Perilaku manusia berhubungan dengan lingkungan hidup (Heimstra dan McFarling, 1974). Salah satu hubungan antara penurunan kualitas lingkungan hidup dan manusia (sosial) yaitu sebagian besar penurunan kualitas lingkungan hidup hasil dari tindakan atau perilaku manusia (Barry, 2007). Kepribadian manusia itu sendiri dan situasi/keadaan lingkungan sekitar akan mempengaruhi perilaku lingkungan seseorang (Laurens, 2012). Perilaku manusia dapat mengakibatkan perubahan-perubahan pada lingkungan hidup (Susilo, 2012).

Perilaku masyarakat kawasan bantaran sungai tidak semua dibahas dalam penelitian ini. Perilaku yang diteliti yaitu pertama, perilaku masyarakat yang membuang air limbah domestik (mencuci, memasak, dan mandi) berasal dari rumah tangga dibuang ke sungai. Perilaku yang kedua yaitu masyarakat yang mengambil tanah dari bukit/gunung sebagai bahan baku pembuatan batu bata. Pembangunan di Kota Tarakan membutuhkan sumberdaya alam seperti tanah. Tanah dapat dipergunakan untuk membangun perumahan atau perkantoran. Interaksi antara populasi manusia dan penggunaan lahan juga terjadi di perkotaan (Yongliang dkk., 2010). Penduduk perkotaan yang tinggal berdekatan dengan sungai akan menyebabkan pergerakan tanah seperti erosi dan tanah longsor (Goransson dkk., 2015). Perilaku ketiga yaitu perilaku yang tidak mengolah kotoran ayam. Perilaku yang keempat yaitu perilaku menambang pasir di sungai. Perilaku-perilaku tersebut dapat mempengaruhi tekanan potensi sumber daya air. Tekanan potensi sumberdaya air dapat menyebabkan persediaan air tidak mencukupi, kualitas air memburuk dan aliran air permukaan rendah (Saimy dan Yusof, 2013).

Rumusan masalah adalah air Sungai Karang Anyar sebagai sumber air bersih harus baik kualitas airnya padahal kualitas air Sungai Karang Anyar menurun. Tujuan penelitian ini adalah memahami perilaku masyarakat kawasan bantaran sungai dalam perlakuan aliran sungai dan menguji penurunan kualitas air Sungai Karang Anyar.

\section{METODE PENELITIAN}

\section{Waktu dan Lokasi}

Penelitian ini dilaksanakan selama 4 bulan yaitu dimulai dari Agustus-Oktober 2014 dan Mei 2015. Tempat penelitian adalah hulu Sungai Karang Anyar sampai water intake PDAM Kampung Bugis, Kelurahan Karang Anyar dan Kelurahan Kampung 1 Skip, Kota Tarakan, Kalimantan Utara. Adapun lokasi penelitian diperlihatkan pada Gambar 1 dan Gambar 2.

Ada beberapa faktor pertimbangan tempat penelitian di Kota Tarakan yaitu pusat pengembangan pembangunan bagian utara Kalimantan. Pendekatan penelitian ini menggunakan pendekatan kualitatif. Metode yang digunakan dalam penelitian ini gabungan antara kuantitatif dan kualitatif. Metode kuantitatif antara lain digunakan untuk teknik pengumpulan data melalui kuesioner dan menghitung status mutu air Sungai Karang Anyar menggunakan metode Indeks Pencemaran. Data yang telah terkumpul melalui kuesioner berjumlah 339 responden. Metode penetapan jumlah sampel menggunakan kesepakatan statistik yaitu minimal 30 orang. Metode penarikan sampel berdasarkan purposive sampling. Adapun kriteria masyarakat yang bermukim adalah 1 orang untuk setiap tempat tinggal.

Metode kuantitatif yang lain dipergunakan adalah penentuan status mutu air dapat menggunakan metoda Indeks Pencemaran (Ali dkk., 2013). Pertimbangan menggunakan metode Indeks Pencemaran karena tidak ada perbedaan antara jenis kontaminan fisik, kimia maupun biologi (Marganingrum, 2013). Indeks Pencemaran berdasarkan Keputusan Menteri Negara Lingkungan Nomor 115 Tahun 2003 tentang Pedoman Penentuan Status Mutu Air (Anonim, 2003). Indeks Pencemaran bagi peruntukan (j) yang adalah fungsi dari $\mathrm{C}_{\mathrm{i}} / \mathrm{L}_{\mathrm{ij}}$ dapat ditentukan dengan persamaan (1).

$$
\mathrm{PIj}=\sqrt{\frac{\left(\mathrm{C}_{\mathrm{i}} / \mathrm{L}_{\mathrm{ij}}\right)_{\mathrm{M}^{2}+\left(\mathrm{C}_{\mathrm{i}} / \mathrm{L}_{\mathrm{ij}}\right)_{\mathrm{R}}^{2}}^{2}}{2}}
$$

Keterangan:

$\mathrm{Ci}=$ Konsentrasi parameter kualitas air

Lij = Konsentrasi parameter kualitas air pada baku peruntukan air (j)

$\mathrm{PIj} \quad=$ Indeks Pencemaran/Pollution Index bagi peruntukan $(\mathrm{j})$

$\left(\mathrm{C}_{\mathrm{i}} / \mathrm{L}_{\mathrm{ij}}\right)_{\mathrm{M}}=\left(\mathrm{C}_{\mathrm{i}} / \mathrm{L}_{\mathrm{ij}}\right)$ maksimum

$\left(\mathrm{C}_{\mathrm{i}} / \mathrm{L}_{\mathrm{ij}}\right)_{\mathrm{R}}=\left(\mathrm{C}_{\mathrm{i}} / \mathrm{L}_{\mathrm{ij}}\right)$ rata-rata

Evaluasi terhadap nilai PI (Pollution Index)

$0 \leq \mathrm{PI}_{\mathrm{j}} \leq 1,0 \rightarrow$ Memenuhi baku mutu (kondisi baik)

$1,0<\mathrm{PI}_{\mathrm{j}} \leq 5,0 \rightarrow$ Cemar ringan

$5,0 \leq \mathrm{PI}_{\mathrm{j}} \leq 10 \rightarrow$ Cemar sedang

$\mathrm{PI}_{\mathrm{j}}>10 \rightarrow$ Cemar berat 


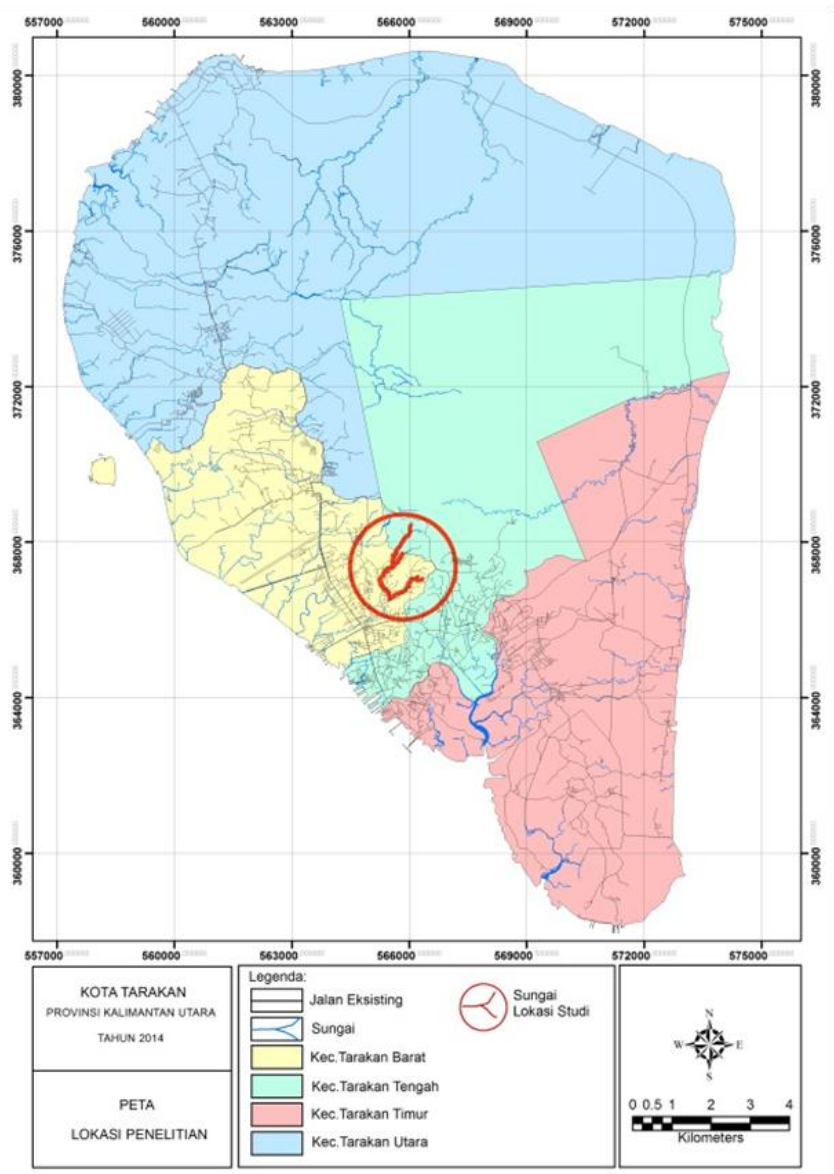

Gambar 1. Peta lokasi penelitian (Anonim, 2011).

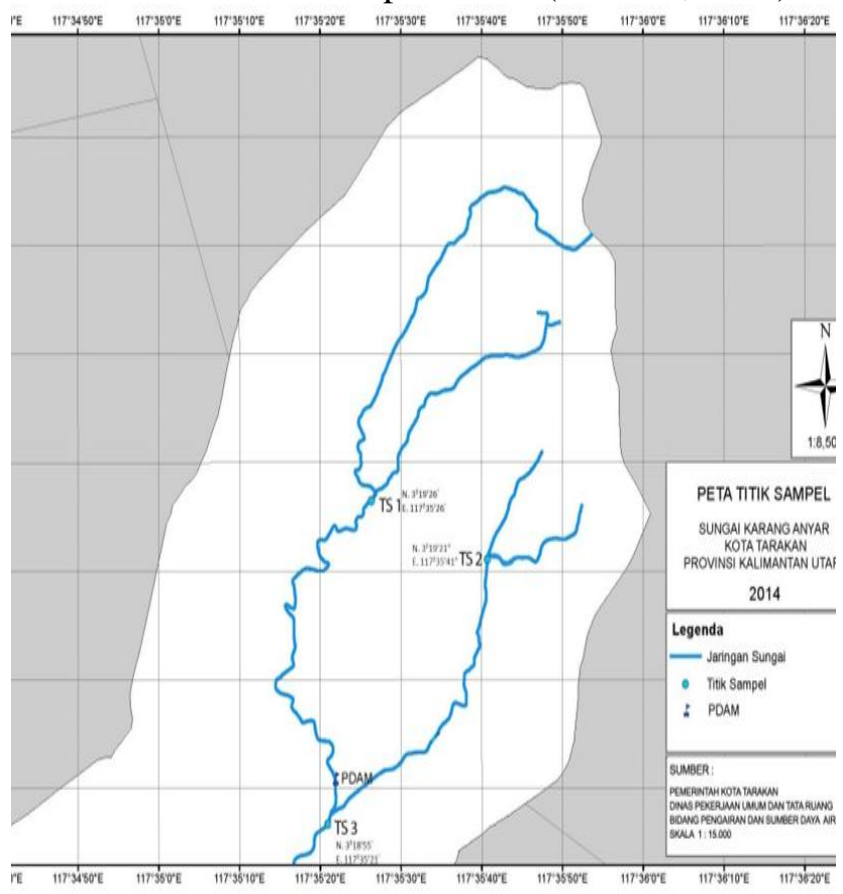

Gambar 2. Titik lokasi pengambilan sampel air Sungai Karang Anyar (Sumber: Anonim, 2011).

Penelitian ini juga menggunakan metode kualitatif. Metode kualitatif yang dipergunakan antara lain digunakan untuk observasi, wawancara mendalam kepada swasta dan tokoh masyarakat. Observasi dilakukan pada perilaku masyarakat yang bermukim di kawasan bantaran sungai. Perilaku masyarakat yang diobservasi adalah perilaku masyarakat di permukiman (membuang air limbah cucian, memasak dan mandi langsung ke sungai), perilaku masyarakat yang tidak mengolah kotoran ayam (peternak ayam), perilaku masyarakat yang menambang pasir di sungai (penambang pasir) dan perilaku yang mengambil tanah di bukit/gunung untuk bahan baku batu bata.

Informan dalam wawancara mendalam adalah sebagian masyarakat yang berkegiatan ternak ayam, pembuatan batu bata dan penambang pasir sungai di kawasan bantaran sungai. Kelompok ini dipilih yang berlokasi hulu Sungai Karang Anyar sampai water intake PDAM Kampung Bugis (Kelurahan Karang Anyar dan kelurahan Kampung I Skip Kota Tarakan) dengan jarak $50 \mathrm{~m}$ dari bantaran sungai dan berusia di atas 17 tahun. Informan berjumlah 8 orang. Penentuan informan dilakukan berdasarkan accidental sampling. Informan lain adalah tokoh masyarakat di lokasi yang sama dan kriteria yang sama. Informan berjumlah 3 orang. Penentuan informan dilakukan berdasarkan purposive sampling. Adapun kriteria tokoh masyarakat adalah bertempat tinggal minimal 20 tahun.

Sampel dalam penelitian ini terdiri atas 2 (dua) kelompok. Pertama adalah sebagian masyarakat yang bermukim di kawasan bantaran sungai dari hulu Sungai Karang Anyar sampai water intake PDAM Kampung Bugis (Kelurahan Karang Anyar dan kelurahan Kampung I Skip Kota Tarakan) dengan jarak $50 \mathrm{~m}$ dari bantaran sungai dan berusia di atas 17 tahun. Kedua, percabangan air Sungai Karang Anyar. Pengambilan sampel air sungai sesaat (grab sample). Frekuensi pengambilan sampel air sungai 1 (satu) kali yaitu saat musim kemarau pada tanggal 7 Agustus 2014. Parameter yang diuji yaitu TSS, COD, dan amoniak.

\section{Prosedur}

Prosedur analisis perilaku masyarakat kawasan bantaran sungai dan kualitas air sungai terdiri atas beberapa tahapan. Tahap pertama adalah penentuan wilayah penelitian. Penentuan wilayah penelitian dengan cara survei dari hulu sampai tengah (water intake PDAM) Sungai Karang Anyar. Langkah selanjutnya dilakukan identifikasi dan inventarisasi perilaku masyarakat yang bermukim di kawasan bantaran sungai. Tahap kedua adalah observasi perilaku masyarakat dan pengambilan sampel air Sungai Karang Anyar. Tahap ketiga adalah wawancara mendalam kepada tokoh masyarakat di wilayah penelitian dan perhitungan status mutu air menggunakan metode Indeks Pencemaran. Tahap keempat atau terakhir adalah penentuan pengaruh perilaku masyarakat kawasan bantaran sungai terhadap kualitas air Sungai Karang Anyar. 


\section{HASIL DAN PEMBAHASAN}

\section{Gambaran Umum Tingkat Pendidikan Masyarakat Kawasan Bantaran Sungai Karang Anyar}

Tingkat pendidikan masyarakat di kawasan bantaran Sungai Karang Anyar sebagian besar berpendidikan Sekolah Dasar (SD), Sekolah Menengah Pertama (SMP) dan Sekolah Menengah Atas (SMA) yaitu sebesar $48 \%$ dan $40 \%$. Tingkat pendidikan SD dan SMP termasuk klasifikasi rendah. Tingkat pendidikan SMA termasuk klasifikasi sedang. Tingkat pendidikan perguruan tinggi, akademi dan tidak bersekolah sebagian kecil dimiliki oleh masyarakat kawasan bantaran sungai yaitu 2; 0 dan $10 \%$. Tingkat pendidikan masyarakat kawasan bantaran sungai diperlihatkan pada Gambar 3.

\section{Perilaku Masyarakat}

\section{Perilaku masyarakat membuang air limbah domestik yang berasal dari rumah tangga}

Hasil kuesioner responden pada segmen 1, 2 dan 3 sebagian besar responden membuang air limbah domestik yang berasal dari rumah tangga langsung di buang ke sungai. Hasil observasi bahwa perilaku responden/masyarakat di kawasan bantaran sungai yang membuang air limbah domestik ke sungai karena belum memiliki fasilitas sarana pembuangan air limbah komunal dan tingkat pendidikan masyarakat yang masih rendah. Pengetahuan lingkungan hidup dan informasi lingkungan hidup sangat diperlukan untuk mempengaruhi perilaku masyarakat (Wang dan Reisner, 2011). Nilai-nilai lingkungan mempunyai peran untuk mempengaruhi perilaku (Latif dkk., 2012). Perilaku membuang air limbah domestik sebagian besar dilakukan pada pagi dan sore hari. Hasil temuan observasi yang lain bahwa air limbah domestik yang langsung dibuang ke sungai terdapat busa sabun. Hal ini karena air limbah domestik yang dibuang berasal dari buangan air cucian. Air limbah domestik yang berasal dari buangan air cucian dapat mempengaruhi parameter COD. Air limbah domestik adalah air buangan organik maupun anorganik berasal dari suatu kegiatan (rumah

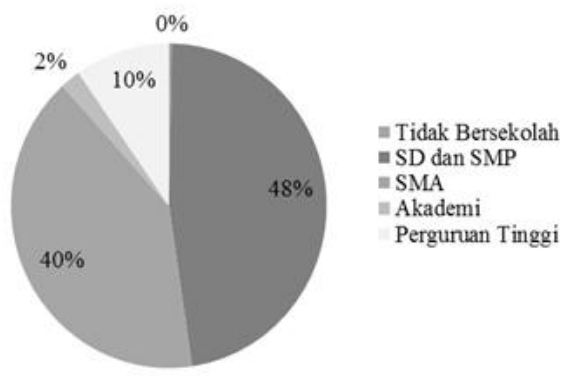

Gambar 3. Tingkat pendidikan masyarakat kawasan bantaran Sungai Karang Anyar. tangga) yang dibuang ke dalam saluran (Mustofa, 2000). Limbah domestik seperti air buangan rumah tangga, sampah, air cucian akan mempengaruhi tingkat kandungan COD dalam sungai (Hendrawan, 2005). Pembuangan air limbah domestik yang di buang ke sungai diperlihatkan pada Gambar 4 .

Limbah domestik seperti air cucian dapat mempengaruhi parameter COD dibuktikan dengan hasil uji kualitas air sungai untuk parameter COD yang melebihi baku mutu. Parameter COD yang melebihi baku mutu diperlihatkan pada Gambar 5 .

Hasil uji parameter COD pada segmen 1, 2 dan 3 yaitu $25 \mathrm{mg} / \mathrm{L}, 18 \mathrm{mg} / \mathrm{L}$, dan $35 \mathrm{mg} / \mathrm{L}$. Hasil uji COD pada segmen 1 melebihi 2,5 kali dari nilai baku mutu air sungai, segmen 2 hasil uji COD melebihi 1,8 kali dari nilai baku mutu air sungai dan parameter COD segmen 3 melebihi 3,5 kali dari nilai baku mutu air sungai yang telah ditetapkan. Baku mutu air sungai yang ditetapkan yaitu $10 \mathrm{mg} / \mathrm{L}$. Nilai COD pada segmen 1-3 yang melebihi baku mutu disebabkan perilaku membuang air limbah domestik ke sungai mempengaruhi parameter COD melebihi baku mutu air sungai. Parameter COD yang melebihi baku mutu dapat mempengaruhi kualitas air sungai.

Selain mempengaruhi parameter COD, perilaku membuang air limbah domestik langsung ke sungai juga mempengaruhi parameter amoniak melebihi baku mutu air sungai. Air limbah domestik dapat mempengaruhi parameter amoniak disebabkan oleh air limbah domestik yang dibuang langsung ke sungai ada yang bersifat organik. Bahan organik akan mengalami dekomposisi oleh mikroorganisme

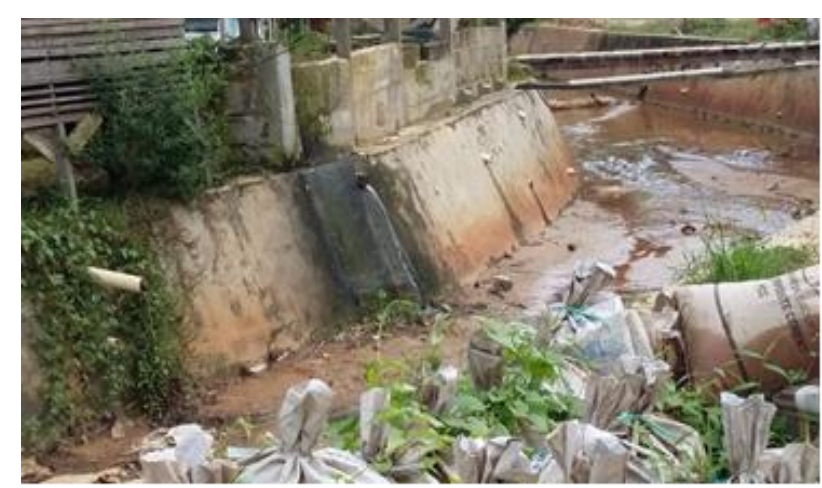

Gambar 4. Air limbah domestik yang dibuang langsung ke Sungai Karang Anyar berasal dari rumah tangga.

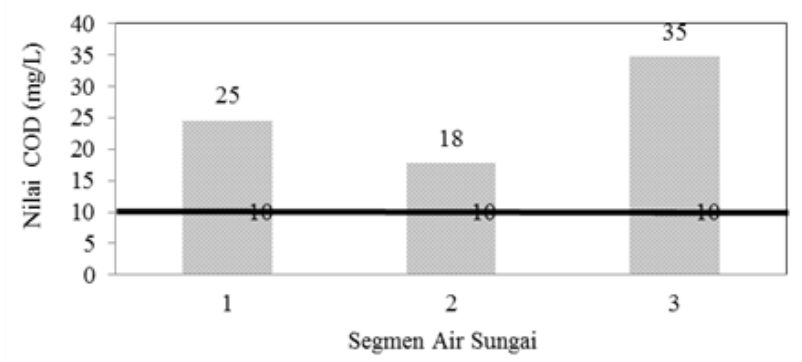

Gambar 5. Hasil uji kualitas air sungai untuk parameter COD. 
sehingga bahan organik tersebut membusuk. Limbah amoniak berasal dari dekomposisi bahan organik oleh mikroba yang berasal dari perumahan, dan pertanian (Effendi dkk., 2009). Bahan organik yang membusuk akan mempengaruhi parameter amoniak.

Air limbah domestik berasal dari air buangan memasak rumah tangga juga langsung dibuang ke sungai. Air buangan memasak bersifat organik. Pencemaran air sungai dapat berasal dari limbah organik dari manusia, hewan, dan tanaman (Hendrawan, 2005). Hasil temuan observasi juga bahwa air limbah domestik yang langsung dibuang ke sungai berasal dari hasil air buangan memasak dari rumah tangga. Pencemaran amoniak berasal dari aktivitas buangan air limbah dari lingkungan permukiman masyarakat dan pengerukan jalan air yang akan melepaskan nutrien yang terkandung dalam lumpur di sungai/saluran drainase (Dumairy, 1992). Nitrogen dalam air bersumber dari limbah peternakan, limbah pertanian dan limbah domestik (Manik, 2009). Perilaku yang membuang air limbah domestik yang bersifat organik langsung ke sungai secara terus-menerus pada segmen 1, 2, 3 dan lamanya masyarakat tinggal di kawasan bantaran sungai mempengaruhi parameter amoniak melebihi baku mutu pada segmen 1, 2, dan 3. Limbah domestik seperti air buangan memasak dapat mempengaruhi parameter amoniak dibuktikan dengan hasil uji kualitas air sungai untuk parameter amoniak yang melebihi baku mutu. Parameter amoniak yang melebihi baku mutu diperlihatkan pada Gambar 6.

Hasil uji parameter amoniak pada segmen 1, 2 dan 3 yaitu 1,13 mg/L; 0,80 mg/L; dan 11,35 mg/L. Hasil uji amoniak pada segmen 1 melebihi 2,3 kali dari nilai baku mutu air sungai, segmen 2 hasil uji amoniak melebihi 1,6 kali dari nilai baku mutu air sungai dan parameter amoniak segmen 3 melebihi 22,7 kali dari nilai baku mutu air sungai yang telah ditetapkan. Baku mutu air sungai yang ditetapkan yaitu $0,5 \mathrm{mg} / \mathrm{L}$.

Nilai parameter COD dan amoniak yang melebihi disebabkan oleh perilaku masyarakat yang tidak berwawasan lingkungan dalam menjalankan aktivitas sehari-hari. Aktivitas manusia yang terus menerus dilakukan tanpa menjaga kelestarian lingkungan hidup akan mempengaruhi polusi lingkungan dan Sumber Daya Alam (SDA) akan berkurang (Khaperskaya, 2015). Parameter COD dan amoniak yang melebihi baku mutu dapat mempengaruhi kualitas air Sungai Karang Anyar. Pengaruh parameter COD dan amoniak yang melebihi baku mutu dapat mempengaruhi kualitas air Sungai Karang Anyar dapat diketahui dengan perhitungan status mutu air menggunakan metode Indeks Pencemaran. Berdasarkan hasil perhitungan status mutu air menggunakan metode Indeks

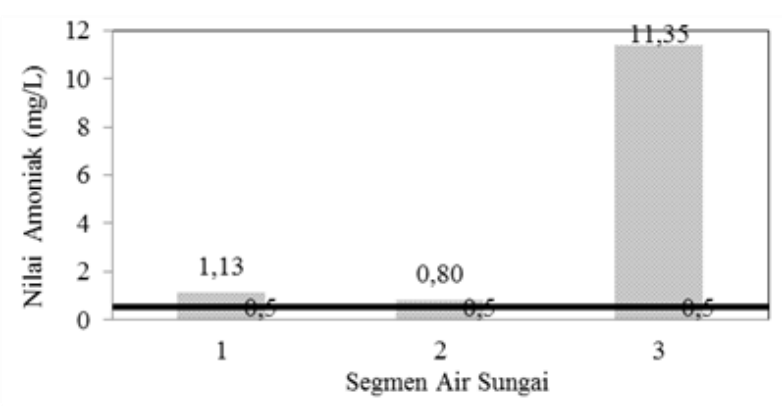

Gambar 6. Hasil uji kualitas air sungai untuk parameter amoniak.

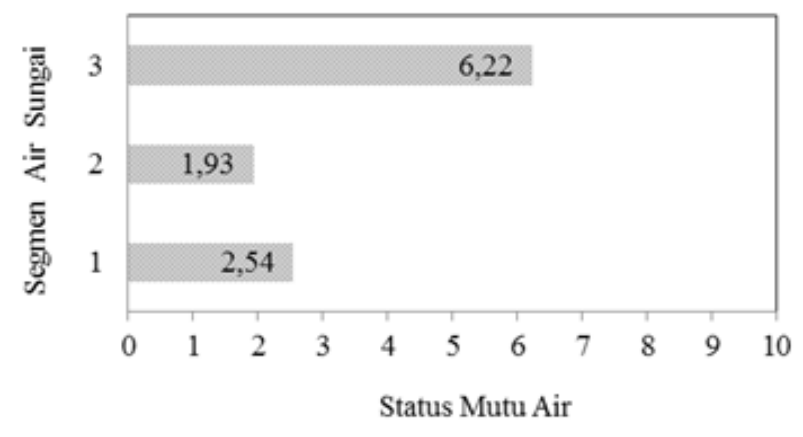

Gambar 7. Status mutu air Sungai Karang Anyar. Keterangan: $0-1=$ memenuhi baku mutu, $1-5=$ cemar ringan, $5-10=$ cemar sedang, dan $>10=$ cemar berat.

Pencemaran pada Rumus 1 bahwa kondisi kualitas air Sungai Karang Anyar tercemar ringan dan sedang. Status mutu air Sungai Karang Anyar yang tercemar diperlihatkan pada Gambar 7. Parameter COD dan amoniak yang melebihi baku mutu menyebabkan air Sungai Karang Anyar pada segmen 1-2 tercemar ringan dan segmen 3 tercemar sedang.

\section{Perilaku masyarakat tidak mengolah kotoran ayam}

Kegiatan yang terdapat di kawasan bantaran sungai selain perumahan adalah ternak ayam. Berdasarkan hasil wawancara mendalam jumlah ayam yang diperlihara antara 800-3.000 ekor ayam. Jumlah ayam ternak yang dipelihara banyak maka jumlah kotoran ayam yang dihasilkan juga banyak. Dari hasil observasi ditemukan bahwa kotoran ayam pada saat panen masih dalam kondisi basah dan mengalir ke sungai. Lokasi kandang ayam berdekatan dengan air sungai. Kotoran ayam dibuang langsung ke tanah. Lokasi kandang ayam diperlihatkan pada Gambar 8.

Berdasarkan hasil observasi bahwa jumlah kotoran ayam yang dihasilkan banyak, lokasi kandang ayam yang berdekatan dengan air sungai, kotoran ayam langsung dibuang langsung ke tanah tanpa diolah terlebih dahulu, kondisi kotoran ayam masih basah dan mengalir ke sungai. Kotoran ayam yang mengalir ke sungai dan mengalami pembusukan akan mempengaruhi nilai parameter 


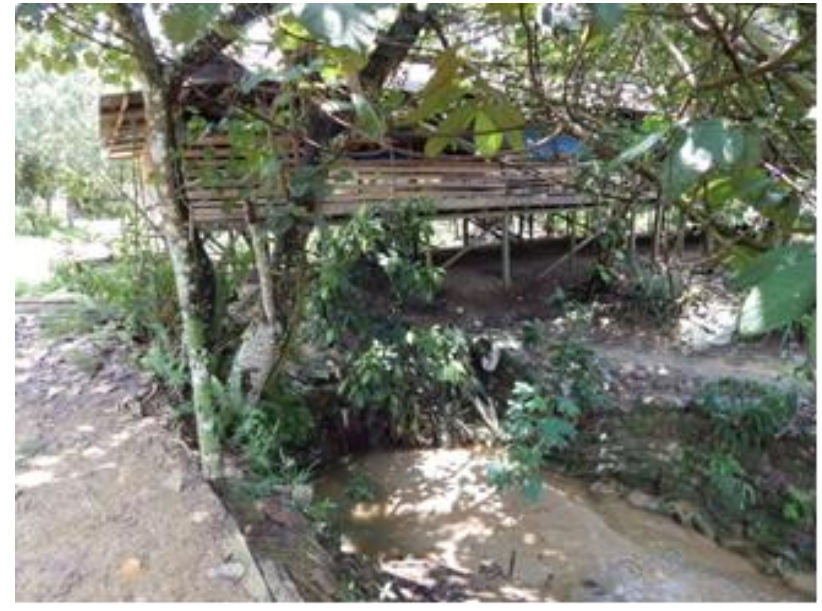

Gambar 8. Lokasi kandang ayam yang berdekatan dengan Sungai Karang Anyar.

amoniak dan kualitas air Sungai Karang Anyar. Hal ini dibuktikan dengan nilai parameter amoniak melebihi baku mutu dan kualitas air sungai telah tercemar. Kotoran ayam yang mengalir ke sungai dan mengalami pembusukan akan mempengaruhi parameter amoniak dibuktikan dengan hasil uji kualitas air sungai untuk parameter amoniak yang melebihi baku mutu. Parameter amoniak yang melebihi baku mutu diperlihatkan pada Gambar 6 .

Berdasarkan hasil wawancara mendalam bahwa kotoran ayam hanya dikerok, dikumpulkan dan dimasukkan dalam karung. Kegiatan tersebut dilakukan setelah panen dan kotoran ayam telah kering. Kegiatan panen ayam berkisar antara 35-39 hari. Hal ini menyebabkan kotoran ayam tersebut mengalami pembusukan. Salah satu bahan pencemar amoniak dihasilkan dari pembusukan kotoran hewan atau pembusukan tanaman yang masuk ke dalam air (Sastrawijaya, 1991). Tanah dan sedimen yang mengandung karbon organik dan nitrogen terutama diperoleh dekomposisi dari tumbuhan dan hewan atau plankton atau antropogenik sumber seperti kontaminan pupuk kimia pupuk atau limbah organik yang kaya nitrogen (Avramidis dkk., 2015).

\section{Perilaku masyarakat mengambil tanah dari bukit/gunung untuk membuat batu bata}

Kegiatan pembuatan batu bata terdapat di kawasan bantaran sungai. Hasil temuan wawancara mendalam kepada informan bahwa jumlah batu bata untuk 1 kali pembakaran berkisar antara 60.00080.000 buah batu bata. Jumlah batu bata untuk dibakar semakin banyak, maka semakin banyak pula tanah yang diambil dari bukit/gunung. Jumlah volume tanah yang diambil dari bukit/gunung semakin banyak maka semakin luas perubahan tutupan lahan. Perubahan tutupan lahan yang semakin besar menyebabkan air limpasan juga semakin besar (Asdak, 2002). Kegiatan manusia yang mengubah bentang alam akan mempengaruhi

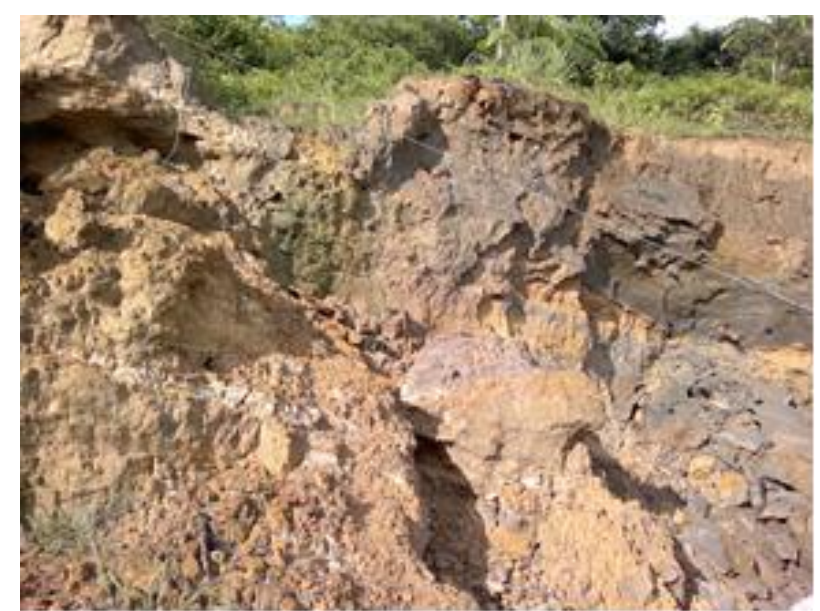

Gambar 9. Bukit/gunung setelah pengambilan tanah untuk pembuatan batu bata.

secara terus- menerus sedimen di sungai (Restrepo dan Kettner, 2012). Perubahan tutupan lahan terjadi karena kondisi awal bukit/gunung sebelum pengambilan tanah masih terdapat semak dan pohon dan setelah pengambilan tanah kondisi bukit/gunung sudah tidak ada tanaman (semak dan pohon). Semak dan pohon di bukit/gunung berfungsi sebagai tutupan lahan agar tanah tidak mudah terkikis, terangkut pada saat hujan dan mengalir ke sungai. Hasil temuan observasi juga bahwa kondisi sekitar bukit/gunung yang belum diambil tanahnya masih terdapat semak dan pohon. Kondisi bukit/gunung yang diambil tanah untuk pembuatan batu bata diperlihatkan pada Gambar 9.

Perilaku masyarakat yang mengambil tanah di bukit/gunung dapat menyebabkan erosi. Jenis tanah pada daerah penelitian adalah Latosol dan Podsolik. Jenis tanah Latosol tergolong jenis tanah yang agak peka terhadap erosi. Jenis tanah Podsolik tergolong jenis tanah yang peka terhadap erosi. Jumlah batu bata yang dihasilkan banyak dan jenis tanah dapat menyebabkan semakin banyak tanah yang mudah terkikis, terangkut pada saat hujan dan mengalir ke sungai maka secara tidak langsung jumlah padatan tersuspensi total di air sungai tinggi. Jumlah padatan tersuspensi yang tinggi dapat menyebabkan kekeruhan yang tinggi di sungai. Kekeruhan yang tinggi dapat menghalangi sinar cahaya matahari yang masuk ke dalam air sungai. Sinar cahaya matahari yang terhalang masuk oleh kekeruhan dapat menyebabkan tanaman air susah untuk melakukan proses fotosintesis sehingga jumlah oksigen terlarut sedikit. Cahaya matahari yang masuk ke dalam air jernih dapat membuat tanaman air berfotosistesis sehingga menghasilkan oksigen terlarut yang tinggi dalam air (Nurudin dkk., 2013). Oksigen terlarut berpengaruh besar terhadap kelimpahan ikan di suatu perairan (Purwanto dkk., 2014). Oksigen terlarut sangat diperlukan bagi ikan. Tingkat kekeruhan yang tinggi dapat menyebabkan stress bahkan kematian pada ikan (Purwanto dkk., 


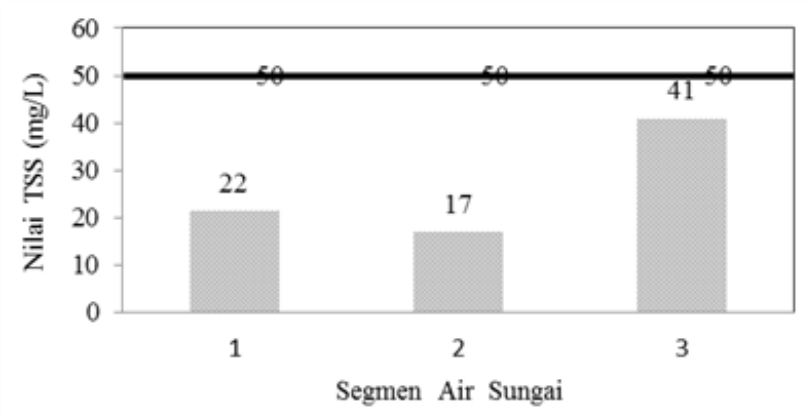

Gambar 10. Hasil uji kualitas air sungai untuk parameter padatan tersuspensi total.

2014). Perilaku masyarakat yang mengambil tanah di bukit/gunung ternyata tidak mempengaruhi parameter padatan tersuspensi total/Total Suspended Solid. Nilai parameter Total Suspended Solid (TSS) diperlihatkan pada Gambar 10.

Hasil uji parameter padatan tersuspensi total pada segmen 1, 2 dan 3 yaitu $22 \mathrm{mg} / \mathrm{L}, 17 \mathrm{mg} / \mathrm{L}$, dan $41 \mathrm{mg} / \mathrm{L}$. Hasil uji untuk parameter padatan tersuspensi total pada semua segmen tidak melebihi baku mutu air sungai yang telah ditetapkan. Baku mutu air sungai yang ditetapkan yaitu $10 \mathrm{mg} / \mathrm{L}$.

Nilai parameter padatan tersuspensi total pada semua segmen tidak melebihi baku mutu air sungai padahal perubahan tutupan lahan semakin luas. Kegiatan manusia untuk mengeksploitasi sumberdaya air dan tanah akan mengurangi kualitas air (Peilin dan Minghong, 2012). Air limpasan yang besar akan menyebabkan tanah terkikis, terangkut, dan mengalir lebih banyak ke sungai (Suripin, 2002).

Padatan tersuspensi total pada musim kemarau di sungai tidak terlalu banyak terkikis dan mengalir ke sungai sehingga nilai padatan tersuspensi total tidak melebihi baku mutu. Padatan tersuspensi total tidak melebihi baku mutu maka padatan tersuspensi total tidak mempengaruhi penurunan kualitas air Sungai Karang Anyar. Faktor yang mempengaruhi padatan tersuspensi total tidak melebihi baku mutu adalah curah hujan. Volume air limpasan mempunyai hubungan dengan curah hujan (Ceretta dkk., 2000). Tanah akan terkikis, terangkut oleh air limpasan pada saat musim hujan dan mengalir ke sungai, tetapi tanah tidak akan terkikis, terangkut oleh air limpasan pada saat musim kemarau. Perilaku mengambil tanah dari bukit/gunung tidak mempengaruhi penurunan kualitas air Sungai Karang Anyar karena ada faktor lain yang mempengaruhi yaitu curah hujan. Ada hubungan antara tutupan lahan, curah hujan dan air limpasan. Kemampuan paling lemah air sungai untuk memulihkan diri sendiri pada musim panas/kemarau (Zhang dkk., 2012). Ada interaksi antara curah hujan, penggunaan lahan, ekosistem dan sosial dalam pengelolaan sistem air perkotaan (Flecher dkk., 2013).

\section{Perilaku masyarakat menambang pasir di sungai}

Perilaku penambang pasir sungai juga terdapat di kawasan bantaran sungai. Berdasarkan hasil temuan saat observasi bahwa menambang pasir di sungai tidak dilakukan setiap hari. Perilaku menambang pasir di sungai tidak dilakukan bergantung pada volume pasir. Hasil temuan lain saat observasi adalah kondisi air sungai setelah menambang pasir terdapat pasir yang tersuspensi dan tidak dapat langsung mengendap. Padatan tersuspensi total yang ukurannya lebih kecil dari sedimen, tidak larut dalam air, dan tidak dapat langsung mengendap (Manik, 2009). Pasir yang tersuspensi dan tidak dapat langsung mengendap dapat mempengaruhi nilai parameter padatan tersuspensi total di air Sungai Karang Anyar. Jumlah padatan tersuspensi yang tinggi dapat menyebabkan kekeruhan yang tinggi di sungai. Kekeruhan yang tinggi dapat menghalangi sinar cahaya matahari yang masuk ke dalam air sungai. Sinar cahaya matahari yang terhalang masuk oleh kekeruhan dapat menyebabkan tanaman air susah untuk melakukan proses fotosintesis sehingga jumlah oksigen terlarut sedikit. Oksigen terlarut sangat diperlukan bagi ikan.

Parameter padatan tersuspensi total pada segmen 1, 2 dan 3 tidak melebihi baku mutu telah diperlihatkan pada Gambar 10. Nilai padatan tersuspensi total tidak melebihi baku mutu sehingga parameter padatan tersuspensi total tidak mempengaruhi penurunan kualitas air sungai. Faktor yang mempengaruhi parameter padatan tersuspensi total tidak melebihi baku mutu karena perilaku menambang pasir di sungai tidak dilakukan setiap hari sehingga tidak terlalu banyak volume pasir yang tersuspensi dan tidak dapat langsung mengendap. Perilaku menambang pasir di sungai tidak mempengaruhi penurunan kualitas air Sungai Karang Anyar khusus parameter padatan tersuspensi total.

Perilaku menambang pasir dari sungai juga dapat menyebabkan bahan-bahan organik dari pembuangan air limbah domestik, kotoran ayam yang telah membusuk dan tertimbun di dasar sungai akan terangkut keatas permukaan air dan mengalir ke sungai. Bahan-bahan organik yang membusuk yang terangkut $\mathrm{ke}$ atas permukaan air dapat menyebabkan parameter amoniak melebihi baku mutu. Nilai parameter amoniak pada segmen 1, 2, dan 3 melebihi baku mutu telah diperlihatkan pada Gambar 6. Nilai parameter amoniak yang melebihi baku mutu dapat mempengaruhi penurunan kualitas air sungai. Penurunan kualitas air sungai telah diperlihatkan status mutu air pada Gambar 7. Perilaku menambang pasir di sungai pada segmen 1, 2 , dan 3 mempengaruhi penurunan kualitas air Sungai Karang Anyar khususnya parameter 
Tabel 1. Matriks perilaku masyarakat kawasan bantaran sungai dengan penurunan kualitas air sungai.

\begin{tabular}{|c|c|c|c|c|}
\hline \multirow{2}{*}{$\begin{array}{l}\text { Kegiatan } \\
\text { masyarakat }\end{array}$} & \multicolumn{2}{|c|}{$\begin{array}{l}\text { Pengaruh penurunan } \\
\text { kualitas air sungai }\end{array}$} & \multirow[t]{2}{*}{ Perilaku } & \multirow[t]{2}{*}{ Keterangan } \\
\hline & Ada & Tidak ada & & \\
\hline Rumah tangga & $\sqrt{ }$ & & $\begin{array}{l}\text { Membuang air limbah } \\
\text { domestik langsung ke } \\
\text { sungai }\end{array}$ & $\begin{array}{l}\text { Mempengaruhi parameter COD dan } \\
\text { amoniak pada segmen 1, 2, dan } 3 \\
\text { melebihi baku mutu }\end{array}$ \\
\hline Ternak ayam & $\sqrt{ }$ & & $\begin{array}{l}\text { Tidak mengolah } \\
\text { kotoran ayam }\end{array}$ & $\begin{array}{l}\text { Mempengaruhi parameter amoniak } \\
\text { pada segmen } 1 \text { melebihi baku mutu } \\
\text { karena kotoran ayam membusuk dan } \\
\text { mengalir ke sungai }\end{array}$ \\
\hline $\begin{array}{l}\text { Pembuatan batu } \\
\text { bata }\end{array}$ & & $\sqrt{ }$ & $\begin{array}{l}\text { Mengambil tanah dari } \\
\text { bukit/gunung }\end{array}$ & $\begin{array}{l}\text { Tidak mempengaruhi parameter TSS } \\
\text { pada segmen } 1 \text { karena musim kemarau } \\
\text { sehingga tidak terlalu banyak tanah } \\
\text { yang terkikis dan terangkut oleh air } \\
\text { limpasan }\end{array}$ \\
\hline $\begin{array}{l}\text { Penambang pasir } \\
\text { di sungai }\end{array}$ & $\sqrt{ }$ & & $\begin{array}{l}\text { Menambang pasir di } \\
\text { sungai }\end{array}$ & $\begin{array}{l}\text { a. Mempengaruhi parameter amoniak } \\
\text { melebihi baku mutu pada segmen } 1 \text {, } \\
2 \text {, dan } 3 \text { karena air limbah domestik, } \\
\text { kotoran ayam yang membusuk dan } \\
\text { tertimbun lama di dasar sungai akan } \\
\text { terangkut keatas dan mengalir di } \\
\text { permukaan air sungai }\end{array}$ \\
\hline & & $\sqrt{ }$ & & $\begin{array}{l}\text { b. Tidak mempengaruhi parameter } \\
\text { TSS pada segmen } 1,2 \text {, dan } 3 \text { karena } \\
\text { kegiatan tidak dilakukan setiap hari, } \\
\text { penambang pasir bergantung pada } \\
\text { curah hujan dan volume pasir }\end{array}$ \\
\hline
\end{tabular}

Sumber : Hasil pengamatan.

amoniak. Kesimpulan perilaku dapat diperlihatkan pada matriks perilaku masyarakat kawasan bantaran sungai dengan penurunan kualitas air sungai pada Tabel 1 .

Berdasarkan Tabel 1 bahwa perilaku masyarakat di kawasan bantaran sungai yang membuang air limbah domestik ke sungai, perilaku masyarakat yang tidak mengolah dan perilaku yang menambang pasir di sungai mempengaruhi parameter COD dan amonia melebihi baku mutu sehingga kualitas air Sungai Karang Anyar tercemar. Perilaku yang tidak berwawasan lingkungan dilatarbelakangi oleh tingkat pendidikan masyarakat yang masih rendah. Faktor penyuluhan dan sosialisasi dari pemerintah daerah yang minim terkait pengelolaan air sungai menyebabkan kesadaran dan pemahaman masyarakat yang bermukim di kawasan bantaran sungai terkait pengelolaan air sungai juga masih minim. Hasil temuan wawancara mendalam kepada informan bahwa tidak ada penyuluhan dari pemerintah daerah terkait pengelolaan air sungai. Informasi dan pengetahuan yang diperoleh masyarakat kawasan bantaran terkait pengelolaanair sungai masih minim. Hasil kuesioner mengenai tingkat pendidikan masyarakat kawasan bantaran sungai sebagian besar SD dan SMP menyebabkan masyarakat kawasan bantaran sungai kurang paham dan sadar pentingnya air Sungai Karang Anyar. Tingkat pendidikan SD dan SMP adalah rendah. Tingkat pendidikan dapat mempengaruhi nilai-nilai lingkungan dan perilaku seseorang (Latif dkk., 2012). Tingkat pendidikan, pengetahuan dan informasi mempengaruhi perilaku dalam pengelolaan air sungai khususnya perilaku yang membuang air limbah domestik langsung ke sungai. Pengetahuan lingkungan hidup dan informasi lingkungan hidup sangat diperlukan untuk mempengaruhi perilaku masyarakat (Wang dan Reisner, 2011).

Hasil temuan observasi juga bahwa tidak ada Instalasi Pengolahan Air Limbah (IPAL) untuk permukiman masyarakat kawasan bantaran sungai. Pengolahan air limbah tersebut sangat diperlukan untuk mengolah air limbah domestik dari permukiman. Teknologi IPAL tersebut akan menurunkan beban pencemar yang ada di air sungai. Pemulihan atau rehabilitasi sungai dapat meningkatkan kapasitas daya dukung lingkungan dan keanekaragaman biologi (DuBowy, 2013). Pemerintah daerah dapat bekerjasama dengan masyarakat untuk membangun IPAL domestik maupun nondomestik yang berbasis masyarakat. Pengelolaan air Sungai Karang Anyar dapat diselesaikan dengan teknologi dan perubahan perilaku. Masalah lingkungan hidup dapat diselesaikan dengan teknologi yang tepat dan perubahan perilaku (Bell dkk., 2001). 
Perilaku masyarakat kawasan bantaran sungai bahwa tidak semua perilaku masyarakat diduga mempengaruhi penurunan kualitas air sungai (COD, TSS dan amoniak) Karang Anyar Kota Tarakan. Tingkat pendidikan masyarakat kawasan bantaran sungai sebagian besar SD dan SMP menyebabkan masyarakat kawasan bantaran sungai kurang paham dan sadar pentingnya air Sungai Karang Anyar. Kerjasama dan tanggaung jawab antara pemerintah daerah, masyarakat dan swasta sangat diperlukan untuk menurunkan beban pencemaran dan melestarikan air sungai secara berlanjutan.

\section{KESIMPULAN}

Perilaku masyarakat yang mempengaruhi maupun tidak mempengaruhi penurunan kualitas air sungai yaitu perilaku masyarakat yang mempengaruhi penurunan kualitas air sungai antara lain perilaku membuang air limbah domestik langsung ke sungai (parameter COD dan amoniak), perilaku tidak mengolah kotoran ayam (parameter amoniak), dan perilaku menambang pasir di sungai (parameter amoniak). Perilaku masyarakat yang tidak mempengaruhi penurunan kualitas air sungai adalah perilaku mengambil tanah dari bukit/gunung.

\section{DAFTAR PUSTAKA}

Ali, A., Soemarno, dan Purnomo, M., 2013. Kajian Kualitas Air dan Status Mutu Air Sungai Metro di Kecamatan Sukun Kota Malang. Jurnal Bumi Lestari, 13(2):265-274.

Anonim, 2003. Keputusan Menteri Negara Lingkungan Hidup Nomor 115 Tahun 2003 tentang Pedoman Penentuan Status Air. Jakarta.

Anonim, 2011. Survey Inventarisasi Drainase (SID) penanganan banjir Sungai Karang Anyar Kota Tarakan. Laporan. Dinas Pekerjaan Umum dan Tata Ruang Kota Tarakan.

Asdak, C., 2002. Hidrologi dan Pengelolaan Daerah Aliran Sungai. Gadjah Mada University Press. Yogyakarta.

Avramidis, P., Nikolaou, K., dan Bekiari, V., 2015. Total Organic Carbon and Total Nitrogen In Sedimen And Soils: A Comparison Of The Wet Oxidation-Titration Metheod With The Combustion-Infrared Method. Agriculture and Agricultural Science Procedia, 4:425430.

Barry, J., 2007. Environment and Social Theory. Routledge. London.

Bell, P.A., Greene, T.C., Fisher, J.D., dan Baum, A., 2001. Environmental Psychology, fifth edition. Wadsworth Thomson, California.
Ceretta, C.A., Girotto, E., Lourenzi, C.R., Trentin, G., Viera, R.C.B., dan Brunetto, G., 2010. Nutrient Transfer by Runfoff Under No Tillage in A Soil Treated with Successive Application of Pig Slurry. Agriculture, Ecosystems And Environment, 139:689-699.

DuBowy, P.J., 2013. Mississipi River Ecohydrology: Past, Present and Future. Ecohydrology and Ecohydrology, 13:73-83.

Dumairy, 1992. Ekonomika Sumber Daya Air. BPFE. Yogyakarta.

Effendi, H., Romanto dan Warditno, Y., 2015. Water Quality Status of Ciambulawung River, Banten Province Based on Pollution and NSFWQI. Procedia Environmental Sciences, 24:228-237.

Flecher, T.D., Andrieu, H., dan Hamel, P., 2013. Understanding Management and Modelling of Urban Hydrology and Its Consequences for Receiving Water: A State of The Art. Advance in Water Resources, 51:261-279.

Goransson, G., Norman, J., Larson, M., Alen, C., Lars-Rosen, L., 2015. A methodology for estimating risks associated with landslides of contaminated soil into rivers. Jurnal Science of the Total Environment,472:481-495.

Heimstra, N.W., dan McFarling, L., 1974. Environmental Psychology. Wadsworth. California.

Hendrawan, D., 2005. Kualitas Air Sungai dan Situ di DKI Jakarta. Makara-Teknologi, 9(1):1319.

Khaperskaya, A., 2015. Environmental Payment and Their Role in Environmental Management. Procedia-sosial and Behavioral Sciences, 166:222-226.

Latif, S.A., Omar, M.S., Bidin, Y.H., dan Awang, Z., 2012. Environmental Value as a Predictor of Recycling Behavior in Urban Area: A Comparative Study. Procedia-Social and Behavioral Sciences, 50:989-996.

Laurens, J.M., 2012. Changing Behavior and Environment in a Community-Based Program of the Riverside Community. Procedia-Social and Behavioral Sciences, 36:372-382.

Manik, K.E.S., 2009. Pengelolaan Lingkungan Hidup. Djambatan. Jakarta.

Marganingrum, D., 2013. Penilaian Mutu Air Sungai dengan Pendekatan Perbedaan Hasil dari 2 Metode Indeks. Buletin Geologi Tata Lingkungan, 23(3):105-114.

Miller, Jr. G. T., 1982. Living in The Environment. Wadsworth Publishing Company. California.

Mustofa, H.A., 2000. Kamus Lingkungan. PT. Rineka Cipta. Jakarta. 
Nurudin, F.A., Kariada, N., dan Irsadi, A., 2013. Keanekaragaman Jenis Ikan di Sungai Sekonyer Taman Nasional Tanjung Puting Kalimantan Tengah. Unnes J. Life Sci., 2(2):118-125.

Peilin W., dan Minghong T., 2012. Challenges for Sustainable Urbanization: A Casestudy of Water Shortage and Water Environment Change in Shandong, China. Procedia Environmental Sciences, 13:919-927.

Purwanto, H., Pribadi, T.A., dan Martuti, N.K.T., 2014. Struktur Komunitas dan Distribusi Ikan di Perairan Sungai Juwana Pati. Unnes J. Life Sci., 3(1):59-67.

Restrepo, J.D., dan Kettner, A., 2012. Human Induced Discharge Diversion in A Tropical Delta and Its Environmental Implication: The Patia River, Colombia. Journal of Hydrology. 424-425:124-142.

Saimy, I.S., dan Yusof, N.A.M., 2013. The Need for Better Water Policy and Governance in Malaysia. Procedia-Social and Behavioral Science, 81:371-375.
Sastrawijaya, A.T., 1991. Pencemaran Lingkungan. PT. Rineka Cipta. Jakarta.

Suripin., 2002. Pelestarian Sumber Daya Tanah dan Air. Andi Offset. Yogyakarta.

Susilo, R.K.D., 2012. Sosiologi Lingkungan. PT. Rajagrafindo Persada. Jakarta.

Wang F., dan Reisner, A., 2011. Factor Influencing Private and Public Environmental Protection Behaviors: Results from A Survey of Residents in Shanxi, China. Journal of Environmental Management, 92:429-436.

Yongliang S., Rusong W., Lingyun F., Jingsheng L., dan Dongfeng Y., 2010. Analysis on Land Use Change and its Demographic Factor in The Originan Stream Watershed of Tarim River Based on GIS and Statistic. Procedia Environmental Sciences, 2:175-184.

Zhang, Z.M., Wang, X.Y., Zhang, Y., Nan, Z., dan Shen, B.G., 2012. The Over Polluted Water Quality Assessment of Weihi River Based on Kernel Density Estimation. Procedia Environmental Science, 13:1271-1282. 